\title{
PREDICTING THE LITIGATION OUTCOME OF PPP PROJECT DISPUTES BETWEEN PUBLIC AUTHORITY AND PRIVATE PARTNER USING AN ENSEMBLE MODEL
}

\author{
Xiaoxiao ZHENG ${ }^{1}$, Yisheng $\mathrm{LIU}^{1 *}$, Jun JIANG ${ }^{2}$, Linda M. THOMAS ${ }^{3}$, Nan SU${ }^{4}$ \\ ${ }^{1}$ School of Economics and Management, Department of Construction Management, \\ Beijing Jiaotong University, 100044 Beijing, China \\ ${ }^{2}$ Department of Construction Management, Beijing University of Civil Engineering \\ and Architecture, 100044 Beijing, China \\ ${ }^{3}$ School of Integrated Sciences, James Madison University, Harrisonburg, VA 22807, USA \\ ${ }^{4}$ Department of Civil and Construction Engineering, National Yunlin University \\ of Science and Technology, 64002 Yunlin, Taiwan
}

Received 1 August 2019; accepted 25 March 2020

\begin{abstract}
Apart from the loss of time and money, disputes between public authority and private partner in China's public-private partnership (PPP) projects are destroying the government's image of PPP support and the private partner's investment confidence. This article aims to explore the main causes for PPP disputes, present the results of disputes, and then predict the litigation outcomes. Based on 171 PPP litigation cases from China Judgements Online within 2013-2018, the research identified 17 legal factors and explained how these factors influence the litigation outcomes, which are named as "prediction approach" in this study. Nine machine learning (ML) models were trained and validated using the data from 171 cases. The ensemble model of gradient boosting decision tree (GBDT), k-nearest neighbor (KNN) and multi-layer perceptron neural network (MLP) performed best compared with other nine individual ML models, and obtained a prediction accuracy of $96.42 \%$. This study adds meaningful insights to PPP dispute avoidance, such as high compensation of expected revenues could prevent the government from terminating the contract unilaterally. To some extent, if parties consider the case litigation outcome, they are more likely prefer a rational settlement out of court to avoid further aggravation of the dispute, and would also alleviate the pressure of litigation in China.
\end{abstract}

Keywords: public-private partnership (PPP), project management, dispute causes, court decisions, litigation prediction, artificial intelligence, case study.

JEL Classification: C53, D74, D80, K41, L32.

${ }^{\star}$ Corresponding author. E-mail: yshliu1@bjtu.edu.cn 


\section{Introduction}

Public-private partnerships (PPPs) allow non-public sector funds to participate in the public infrastructure projects to make use of the private sector's advanced technology and management experience (Dansoh et al., 2020; Feng et al., 2017). PPP arrangements have been widely introduced for the construction of public infrastructure by a growing number of governments due to advantages, such as saved public investments and improved public service quality and supply efficiency (Carrillo et al., 2008; Dixon et al., 2005; Feng et al., 2017). At the end of 2013, the Chinese government initiated PPP legislative work. Then the Ministry of Finance (MOF) of the People's Republic of China (PRC) and the National Development and Reform Commission (NDRC) began to promote actively the application of PPP method and encourage private capital to participate in infrastructure construction (Cheng et al., 2016). The latest statistics released by the MOF showed that at the end of June 2019, a total of 8,921 projects have been collected by China PPPs Center, with a total investment of 13.5 trillion CNY (Chinese Yuan) (China Public Private Partnerships Center, 2019).

In the past few years, disputes happened during the performance of PPP contracts, which led to many PPP project failures in China (Chan et al., 2015). Compared with traditional construction disputes, PPP disputes occur not only in the building phase, but also in the operation and transfer phases (Chou \& Lin, 2013). More than 500 PPP project cases were resolved through the litigation process from 2013 to 2018 (China Judgements Online, 2018). Nonetheless, the number of lawsuits is increasing yearly.

PPP project disputes are complex and politically influenced, and multiple stakeholders with different interests and values are involved (Marques, 2018; Osei-Kyei et al., 2019). Several examples include concession retraction in advance, termination of PPP contract, and demand below forecast (Cruz \& Marques, 2013a; Osei-Kyei \& Chan, 2017) disputes between public authority and private partner. Financing disputes occur between the private sector and bank or other financial institutions. Insurance disputes can happen between the public authority and insurance agencies. Construction payment, time extension and delay disputes between the private sector and construction contractor are reasons as well for litigation. Subcontract payment and construction materials disputes between construction contractor and subcontractor are other reasons for disagreements. This research considers the disputes between the public government and private partner in China. Although this category of disputes considered probably represent less than half of the total number of PPP lawsuits in China, they have the most direct impact on the success of PPP projects.

At present, few studies and efforts have been conducted on PPP project disputes. Cruz and Marques (2013a, 2013b) identified the exogenous and endogenous determinants that led to renegotiation in PPP projects, and found the evidence of high costs in renegotiation process. Through case study, Marques (2018) put forward some features that should be paid attention to when adopting arbitration to solve PPP disputes. What trigger the PPP dispute? What are the litigation outcomes? The current studies don't answer these questions.

This paper intends to fulfill this gap to predict the PPP dispute litigation outcomes. In view of the skyrocketing growth stage of PPP projects in China, prediction of litigation 
outcome in PPP disputes is necessary and significant: (1) in the preparation stage, the complete contract clauses can be stipulated based on the litigation outcomes, which will help reduce the frequency of disputes occurrence to some extent; (2) depending on the possible outcomes of a dispute, prevention measures can be formulated in the project execution stage to improve the efficiency of dispute settlement, and reduce the cost of time and money in the future; (3) in the dispute negotiation stage, based on the possible outcomes of a lawsuit, the senior managers of PPP project can assess the consequences caused by the litigation proactively, which can help lead to a rational settlement out of court and avoid further aggravation of the dispute (Chaphalkar et al., 2015).

An ensemble model is proposed in this paper to make the prediction result closer to the actual judgment of the court. The court decisions of PPP disputes litigation depend on several complex and interrelated factors (Arditi \& Pulket, 2005; Chau, 2007). With that in mind, the first step in this study was to collect PPP litigation cases from China Judgements Online within 2013-2018, including data filtering, data processing. Then case study method was used subsequently to extract the factors that influenced the decisions of judges. Next the aforementioned factors were used to illustrate the prediction approach, mainly focused on how the legal factors influenced the litigation outcomes. Finally, nine ML models were developed and trained based on the database to predict the litigation outcomes.

The structure of this paper is as follows. The first section discusses the literature on application of ML models in predicting construction litigation outcomes. The second section introduces the research methodology, which provides an explaining of the process of extracting the legal factors (influencing judges' decisions) from the litigation cases. The next section explores the main causes for PPP disputes, the results of disputes, and how the above legal factors lead to the litigation outcomes. Meanwhile, the above analysis can give insight into how to prevent PPP disputes in future. Then, the fourth section presents model implementation and comparisons of model performance based on the data from 171 cases. Finally, conclusions and the future work direction are derived.

\section{Literature review}

Disputes resolved in courts have two obvious disadvantages. One is that litigation process costs parties in a dispute considerably more time (Cheung et al., 2002; Mitropoulos \& Howell, 2001; Treacy, 1995). PPP disputes involve legal, economic and social issues, which makes the case difficult to settle. According to the cases from China Judgements Online, PPP lawsuits usually take about 1 to 5 years before trial. The other is the prolonged, detailed factual investigation process makes litigation cost very high (Chan et al., 2003; Haugen \& Singh, 2015; Mahfouz \& Kandil, 2012; Steen, 1994). Professionals with rich legal, financial knowledge and construction experience are needed in the litigation process, however, such interdisciplinary talents are not very common. Thus their salaries are very high and the fees paid to lawyers and PPP experts are very expensive.

One logical notion that could be forwarded is that if the legal position of litigant parties and the litigation outcome of the disputes can be predicted with some certainty, the 
frequency and severity of litigation could be reduced (Mahfouz \& Kandil, 2012; Pulket \& Arditi, 2009). Therefore, several studies have been conducted to predict the outcome of the construction disputes as accurately as possible. A neural network was developed to predict construction litigation based on 102 cases from the Illinois appellate courts and an accuracy of $66.67 \%$ was obtained by Arditi et al. (1998). The same cases tried in Illinois circuit courts were organized in 43 input features and 1 output feature, and achieved a prediction accuracy of $83.33 \%$ by using case-based reasoning (CBR) (Arditi \& Tokdemir, 1999). Then, other studies based on the same database attained higher prediction rate, $89.59 \%$ in boosted decision trees (BDT) (Arditi \& Pulket, 2005) and 91.15\% in an integrated artificial intelligence model (Arditi \& Pulket, 2010).

There are also several attempts for a specific type of construction prediction. Mahfouz and Kandil (2012) trained nine machine learning (ML) models to predict litigation outcome of DSC (differing site condition) disputes using 400 cases, and the support vector machine (SVM) model attained the best accuracy of $98 \%$ among all the models. For construction disputes raised due to variation clause in Indian, Chaphalkar et al. (2015) proposed a multilayer perceptron (MLP) neural network. The authors identified 16 intrinsic factors that influence the arbitral decisions through a case study approach and then predicted the outcome of this type of dispute based on these factors (Chaphalkar et al., 2015). Kwon et al. (2017) predicted the construction noise (including health problems, environmental pollution, and cost overruns, etc.) prior to the construction based on casebased reasoning.

An important attempt to explore the prediction of dispute propensity in PPP projects was achieved by Chou and Lin (2013). This research was focused on using the project attributes (project location, project scale, type of government agency in charge, etc.) during the project initiation phase to predict whether the dispute would occur or not in the future. The authors indicated that, if the governmental authority knew the potential disputes before project initiation, the decision-support information needed for dispute prevention strategy could be provided before disputes occur.

Although artificial intelligence (AI) techniques are effective tools in predicting the outcome of construction litigation, the researchers rarely analyzed the causes and results of the disputes. The results also do not tell us the different roles of the legal factors on the litigation outcomes. To fill this gap, this paper attempts to explain the process of the court judgment based on the legal factors which are extracted from the litigation cases. Thorough analysis on the litigation outcomes to explore the prevention mechanism for different types of PPP disputes.

\section{Research methodology}

This research paper concentrates on the identification of important legal factors and using them to explain the process of the court's judgment related to Chinese PPP project disputes between public authority and private partner. Then the proposed ML models are developed to predict the litigation outcomes to validate the reliability of the legal factors. The methodology is shown in Figure 1. 


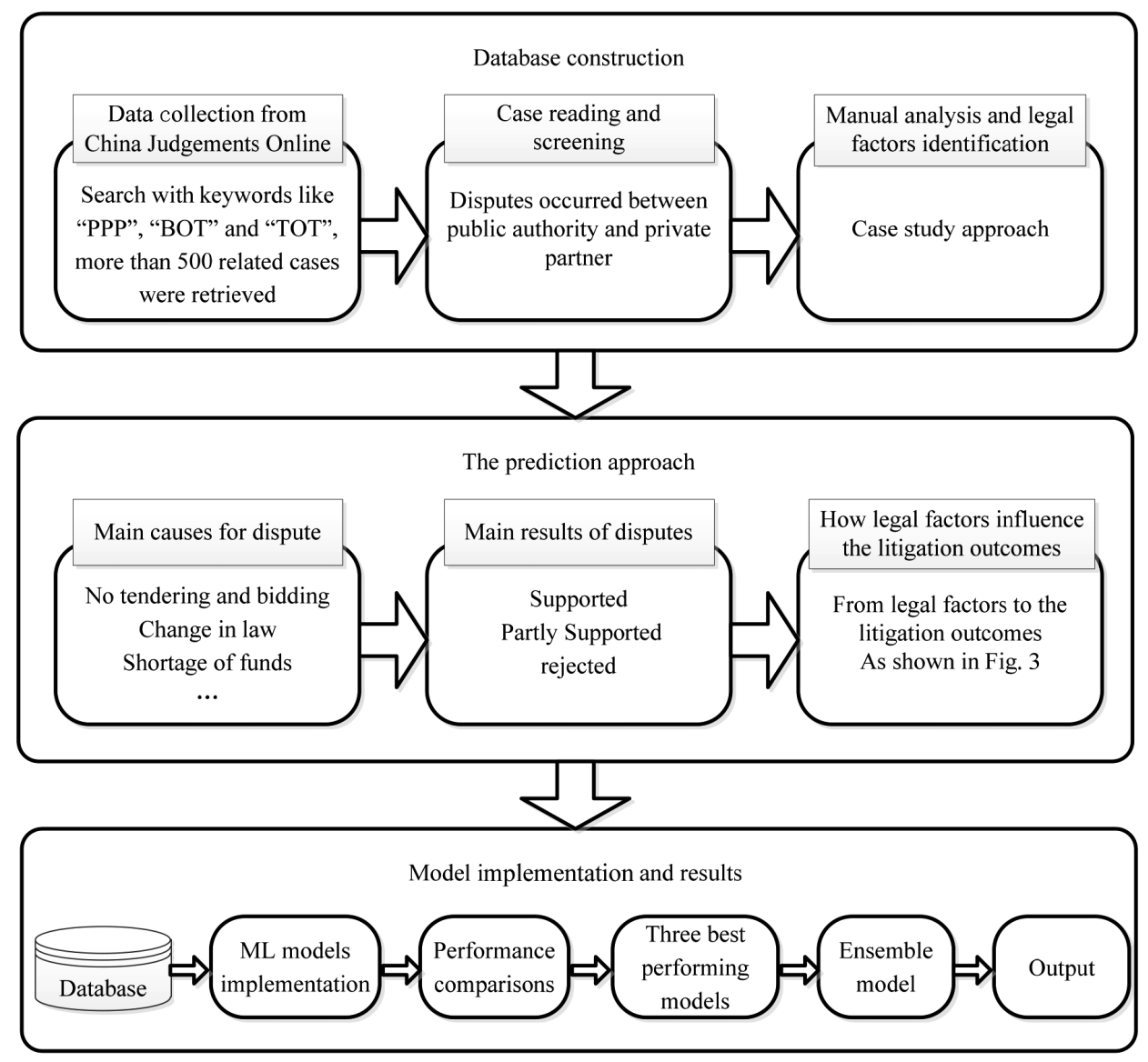

Figure 1. Research methodology

\subsection{Data collection}

In July 2013, the "China Judgements online" website was launched officially. For a number of domains' researches, "China Judgements online" provides a rich set of data and cases for researchers to conduct research by using computer intelligence and data mining technology.

More than 500 cases emerged when searching with keywords like "PPP (public-private partnerships)", "BOT (build-operate-transfer)", “TOT (transfer-operate-transfer)" and "ROT (retrofit-operate-transfer)" and in "China Judgements online" website. The data collection and case study work began in April 2018 and ended in June 2019. Case selection processes reserved disputes between public authority and private partner. Meanwhile, the intact case information was also required. Out of more than 500 lawsuits, 171 cases from July 2013 to June 2019 were selected as the database for this study. In several cases, counterclaims occurred during the trial. Thus, with the addition of 27 counterclaims, the final data set contained data $\mathrm{N}=198$. 


\subsection{Identification of legal factors}

Case study is a widely used research method. It has a prominent place in many disciplines, ranging from psychology, anthropology, sociology, and political science to education, clinical science, social work, and administrative science (Albert et al., 2010; Robert, 2014). In the domain of construction dispute prediction, previous researchers have also used case study approach to perform detailed analysis for each of the cases to extract significant factors which lead to the decisions of judges or arbitrators (Arditi et al., 1998; Arditi \& Tokdemir, 1999; Chaphalkar et al., 2015; Mahfouz \& Kandil, 2009, 2012).

The size of the cases from "China Judgements online" varies between 15 to 35 pages (Chinese language). Each case includes the following sections: a) "introduction of the parties" that presents the basic information of the plaintiff and defendant in the litigation and their respective lawyers; b) a "trial history" section means the trial history of the case, including original trial, counterclaims, appeals and retrials; c) the "case facts" section is a very detailed section, including the plaintiff's claim, defendant's defense, the cause of the dispute, case facts ascertained by the court and the evidence with which the court decided the case in detail; d) a "reason" section elaborates the focus of controversy in the case based on the facts, whether the plaintiff's claim supported, rejected or partially supported, and reasons of the judges' decision; e) the "judgment" section that includes the court judgment and legal provisions supporting the judgment.

For each of the cases, to identify the factors that are hypothesized to have led to the decisions, a deep analysis was conducted to reveal certain logic behind judges' decisions. The logic is in a form of a series of exploratory questions based on the case facts, the focus of controversy, PPP contract, etc., which help the judges during their decision making. Then these exploratory questions were considered when the judges giving their decision were named as "legal factors". In order to better explain the logic, the identification process is explained by sample lawsuits which are listed in Table 1. Table 1 contains case basic information (column 2), the exploratory questions raised by judges (column 3) and factors identified from the judges' decisions for each case (column 4). Due to the limited space, only three cases are given to illustrate the identification process.

Table 1. Identification of factors

\begin{tabular}{|l|l|l|l|}
\hline No. & \multicolumn{1}{|c|}{ Cases } & $\begin{array}{l}\text { Exploratory } \\
\text { questions raised } \\
\text { by judges }\end{array}$ & $\begin{array}{l}\text { Factors identified } \\
\text { from each case }\end{array}$ \\
\hline 1 & $\begin{array}{l}\text { Emergence of competitive project. } \\
- \text { Plaintiff: Private partner } \\
\text { - Defendant: Public authority } \\
\text { - Case description } \\
\text { In a students bathing service PPP project, the private } \\
\text { partner enjoyed 8 years concession duration. In the } \\
\text { second year, the public sector granted the concession } \\
\text { to a third party again which result in the previous } \\
\text { concessionaire's investment couldn't be recovered on } \\
\text { schedule. }\end{array}$ & $\begin{array}{l}\text { - Has the PPP } \\
\text { project been } \\
\text { terminated early? } \\
\text { - Did the com- } \\
\text { petitive projects } \\
\text { emerged ? } \\
\text { - Are there } \\
\text { clauses in the } \\
\text { contract for } \\
\text { exclusion of } \\
\text { competitive }\end{array}$ & $\begin{array}{l}\text { Input factors: } \\
- \text { Premature } \\
\text { termination of } \\
\text { the project. }\end{array}$ \\
$\begin{array}{l}\text { Emergence of } \\
\text { competitive } \\
\text { projects. } \\
\text { - Provision of } \\
\text { clauses in the } \\
\text { contract for } \\
\text { exclusion of }\end{array}$ \\
\hline
\end{tabular}


Continued Table 1

\begin{tabular}{|c|c|c|c|}
\hline No. & Cases & $\begin{array}{c}\text { Exploratory } \\
\text { questions raised } \\
\text { by judges }\end{array}$ & $\begin{array}{l}\text { Factors identified } \\
\text { from each case }\end{array}$ \\
\hline & $\begin{array}{l}\text { - Plaintiff's claim } \\
\text { The plaintiff claimed to terminate the contract and } \\
\text { asked for the return of investment, demanding } \\
\text { compensation for interest on investment, expected } \\
\text { revenues and liquidated damages. } \\
\text { - Court judgement } \\
\text { The judges supported the plaintiff's claim. As per } \\
\text { clause } 94 \text { of "The PRC (People's Republic of China) } \\
\text { Contract Law" and PPP contract, the public sector } \\
\text { explicitly guaranteed the unique of the project, the } \\
\text { behavior of granting the concession to a third party } \\
\text { shall be deemed as substantial breach of the contract. }\end{array}$ & $\begin{array}{l}\text { projects? } \\
\text { - Are there } \\
\text { clauses in the } \\
\text { contract for } \\
\text { compensation } \\
\text { of expected } \\
\text { revenues? }\end{array}$ & $\begin{array}{l}\text { competitive } \\
\text { projects. } \\
\text { - Provision of } \\
\text { clauses in the } \\
\text { contract for } \\
\text { compensation } \\
\text { of expected } \\
\text { revenues. } \\
\text { Output factor: } \\
\text { - The claim was } \\
\text { supported. }\end{array}$ \\
\hline 2 & $\begin{array}{l}\text { The public authority didn't build the wastewater } \\
\text { inlet pipe and standard water discharge pipe, which } \\
\text { prevented the wastewater treatment plant from } \\
\text { operating. } \\
\text { - Plaintiff: Private partner } \\
\text { - Defendant: Public authority } \\
\text { - Case description } \\
\text { The plaintiff invested } 24 \text { million RMB to build a } \\
\text { wastewater treatment plant and enjoyed } 20 \text { years } \\
\text { concession duration. However, the defendant didn't } \\
\text { build the wastewater inlet pipe and standard water } \\
\text { discharge pipe. } \\
\text { - Plaintiff's claim } \\
\text { The plaintiff requested to terminate the contract, } \\
\text { and the defendant must repurchase the wastewater } \\
\text { treatment plant and pay liquidated damages. } \\
\text { - Defendant's defense } \\
\text { Residents nearby objected to the construction of the } \\
\text { wastewater treatment plant. } \\
\text { - Court judgement } \\
\text { The judges supported the plaintiff's claim. As per } \\
\text { clause } 94 \text { of "The PRC (People's Republic of China) } \\
\text { Contract Law" and PPP contract, the location of the } \\
\text { wastewater treatment plant was improper which caused } \\
\text { residents' protest. The public authority's default led to } \\
\text { the termination of the project. }\end{array}$ & $\begin{array}{l}\text { - Has the PPP } \\
\text { project been } \\
\text { terminated early? } \\
\text { - Whether } \\
\text { the essential } \\
\text { supporting } \\
\text { facilities were } \\
\text { constructed / } \\
\text { equipped or not? } \\
\text { - Was it the } \\
\text { public authority's } \\
\text { responsibility } \\
\text { to construct } \\
\text { the supporting } \\
\text { facilities? }\end{array}$ & $\begin{array}{l}\text { Input factors: } \\
\text { - Premature } \\
\text { termination of } \\
\text { the project. } \\
\text { - No essential } \\
\text { supporting } \\
\text { facilities. } \\
\text { - Provision of } \\
\text { clauses in the } \\
\text { contract for } \\
\text { public sector's } \\
\text { obligation } \\
\text { to construct } \\
\text { supporting } \\
\text { facilities. } \\
\\
\text { Output factor: } \\
\text { - The claim was } \\
\text { supported. }\end{array}$ \\
\hline 3 & $\begin{array}{l}\text { The public authority retracted the concession during } \\
\text { the operation period. } \\
\text { - Plaintiff: Private partner } \\
\text { - Defendant: Public authority } \\
\text { - Case description } \\
\text { In 2010, the private and the public sector signed a } \\
\text { BOT concession agreement to construct city pipeline } \\
\text { gas project and the private partner enjoyed } 30 \text { years } \\
\text { concession duration. In } 2013 \text {, the public authority } \\
\text { retracted the concession unilaterally and then } \\
\text { authorized it to a third party. }\end{array}$ & $\begin{array}{l}\text { - Has the PPP } \\
\text { project been } \\
\text { terminated early? } \\
\text { - Whether the } \\
\text { public authority } \\
\text { retracted the } \\
\text { concession } \\
\text { unilaterally? } \\
\text { - Has the third } \\
\text { party built or }\end{array}$ & $\begin{array}{l}\text { Input factors: } \\
\text { - Premature } \\
\text { termination of } \\
\text { the project. } \\
\text { - Retracting } \\
\text { the concession } \\
\text { unilaterally. } \\
\text { - The new } \\
\text { concessionaire } \\
\text { has completed }\end{array}$ \\
\hline
\end{tabular}


End of Table 1

\begin{tabular}{|l|l|l|l|}
\hline No. & \multicolumn{1}{|c|}{ Cases } & $\begin{array}{c}\text { Exploratory } \\
\text { questions raised } \\
\text { by judges }\end{array}$ & $\begin{array}{l}\text { Factors identified } \\
\text { from each case }\end{array}$ \\
\hline & $\begin{array}{l}\text { - Plaintiff's claim } \\
\text { The administrative action (retracting the concession } \\
\text { right during the operation period) should be confirmed } \\
\text { as illegal and continue to perform the contract. } \\
\text { - Defendant's defense }\end{array}$ & $\begin{array}{l}\text { operated the new } \\
\text { project? }\end{array}$ & $\begin{array}{l}\text { the construction } \\
\text { of the new } \\
\text { project or put it } \\
\text { into operation. }\end{array}$ \\
$\begin{array}{l}\text { project could not meet the residents' demand for } \\
\text { pipeline gas. } \\
\text { - Court judgement } \\
\text { By the time of the case trial stage, the third party } \\
\text { (new private partner) had completed the expansion } \\
\text { construction of gas pipeline and put it into operation. } \\
\text { The cancellation of the administrative action would } \\
\text { bring great losses to the public interest. As per clause } 74 \\
\text { of "The PRC (People's Republic of China) Administrative } \\
\text { Procedure Law", the court made a judgment confirming } \\
\text { the administrative action was illegal. }\end{array}$ & $\begin{array}{l}\text { Output factor: } \\
\text { - The claim was } \\
\text { partly supported. }\end{array}$ \\
\hline
\end{tabular}

Note: Clause 94 of "The PRC (People's Republic of China) Contract Law", "Legally Prescribed Conditions Giving Rise to Termination Right. The parties may terminate a contract if: (i) force majeure frustrated the purpose of the contract; (ii) before the time of performance, the other party expressly stated or indicated by its conduct that it will not perform its main obligations; (iii) the other party delayed performance of its main obligations, and failed to perform within a reasonable time after receiving demand for performance; (iv) the other party delayed performance or otherwise breached the contract, thereby frustrating the purpose of the contract; (v) any other circumstance provided by law occurred." Clause 74 of "The PRC (People's Republic of China) Administrative Procedure Law", "Administrative actions should be canceled in accordance with the law, however, the cancellation will cause great damage to the national, social and public interests. The court should make a decision that the administrative action is illegal and it couldn't be canceled."

As a result, 17 significant factors are extracted from the database, Table 2 summarizes these 17 factors, their value types and categorical labels.

Table 2. Legal factors

\begin{tabular}{|c|c|c|c|}
\hline No. & Category & Factors & $\begin{array}{l}\text { Classification of } \\
\text { factor values }\end{array}$ \\
\hline 1 & \multirow{5}{*}{ Causes } & No tendering and bidding & $\begin{array}{l}\text { Yes } \\
\text { No }\end{array}$ \\
\hline 2 & & Change in law & $\begin{array}{l}\text { Yes } \\
\text { No }\end{array}$ \\
\hline 3 & & Shortage of funds & $\begin{array}{l}\text { Yes } \\
\text { No }\end{array}$ \\
\hline 4 & & Illegal subcontracting & $\begin{array}{l}\text { Yes } \\
\text { No }\end{array}$ \\
\hline 5 & & Unqualified public service & $\begin{array}{l}\text { Yes } \\
\text { No }\end{array}$ \\
\hline
\end{tabular}


End of Table 2

\begin{tabular}{|c|c|c|c|}
\hline No. & Category & Factors & $\begin{array}{l}\text { Classification of } \\
\text { factor values }\end{array}$ \\
\hline 6 & & No essential supporting facilities & $\begin{array}{l}\text { Yes } \\
\text { No }\end{array}$ \\
\hline 7 & & Emergence of competitive projects & $\begin{array}{l}\text { Yes } \\
\text { No }\end{array}$ \\
\hline 8 & & Retracting the concession unilaterally & $\begin{array}{l}\text { Yes } \\
\text { No }\end{array}$ \\
\hline 9 & & Default of payment & $\begin{array}{l}\text { Yes } \\
\text { No }\end{array}$ \\
\hline 10 & & Delays in expropriation & $\begin{array}{l}\text { Yes } \\
\text { No }\end{array}$ \\
\hline 11 & & Demand below forecast & $\begin{array}{l}\text { Yes } \\
\text { No }\end{array}$ \\
\hline 12 & \multirow{4}{*}{$\begin{array}{l}\text { Contract } \\
\text { clauses }\end{array}$} & $\begin{array}{l}\text { Provision of clauses in the contract for compensation } \\
\text { of minimum limit demand. }\end{array}$ & $\begin{array}{l}\text { Yes } \\
\text { No }\end{array}$ \\
\hline 13 & & $\begin{array}{l}\text { Provision of clauses in the contract for compensation } \\
\text { of expected revenues. }\end{array}$ & $\begin{array}{l}\text { Yes } \\
\text { No }\end{array}$ \\
\hline 14 & & $\begin{array}{l}\text { Provision of clauses in the contract for exclusion of } \\
\text { competitive projects. }\end{array}$ & $\begin{array}{l}\text { Yes } \\
\text { No }\end{array}$ \\
\hline 15 & & $\begin{array}{l}\text { Provision of clauses in the contract for public sector's } \\
\text { obligation to construct supporting facilities. }\end{array}$ & $\begin{array}{l}\text { Yes } \\
\text { No }\end{array}$ \\
\hline 16 & \multirow{2}{*}{$\begin{array}{l}\text { Objective } \\
\text { facts }\end{array}$} & Premature termination of the project & $\begin{array}{l}\text { Yes } \\
\text { No }\end{array}$ \\
\hline 17 & & $\begin{array}{l}\text { The new concessionaire have completed the } \\
\text { construction of the new project or put it into operation. }\end{array}$ & $\begin{array}{l}\text { Yes } \\
\text { No }\end{array}$ \\
\hline
\end{tabular}

\subsection{Experimental model}

Nine machine learning models were developed to predict the litigation outcome of PPP project disputes based on the previously identified 17 important factors. These models included (1) support vector machine (SVM); (2) two models based on tree: decision tree (DT) and random forest (RF); (3) multilayer perceptron neural network (MLP) model; (4) logistic regression (LR); (5) k-nearest neighbor (KNN); and (6) three boosting models: gradient boosting decision tree (GBDT), adaptive boosting (AdaBoost) and extreme gradient boosting (XGBoost). The nine models were selected because their outstanding performance in a number of predictive and classified studies of various domains (Chaphalkar et al., 2015; Cheung et al., 2000, 2010; Ding et al., 2018; Doğan et al., 2008; Lee, 2009; Lin et al., 2006; Mahfouz \& Kandil, 2012; Mustapha \& Saeed, 2016; Wang et al., 2018; Wu et al., 2017).

Ensemble methods integrate multiple machine learning models into an ensemble model, which obtain better predictive performance compared with conventional single model (Alexandre et al., 2001; Opitz \& Maclin, 1999; Rogova, 1994; Rokach, 2010). This happens because each individual machine learning model (classifier) tend to make misclassification errors 
on different parts of the input space. These classifiers can be regarded as error independent (Rogova, 1994). In other words, the subset of the input space that each classifier will attribute a correct label will differ from one classifier to another (Alexandre et al., 2001). By using the correct prediction outcome from different classifiers, a combined system of different types of classifiers could obtain a better overall accuracy and reduce the misclassification rate (Alexandre et al., 2001; Opitz \& Maclin, 1999; Rogova, 1994; Rokach, 2010). Therefore, the prediction performance can be improved for a given problem.

The approach of combination is to rank the models listed above and select three best predictive performance models to combine into an ensemble model (Chou \& Lin, 2013). The voting method is often used to assess the aggregation performance (Figure 2).

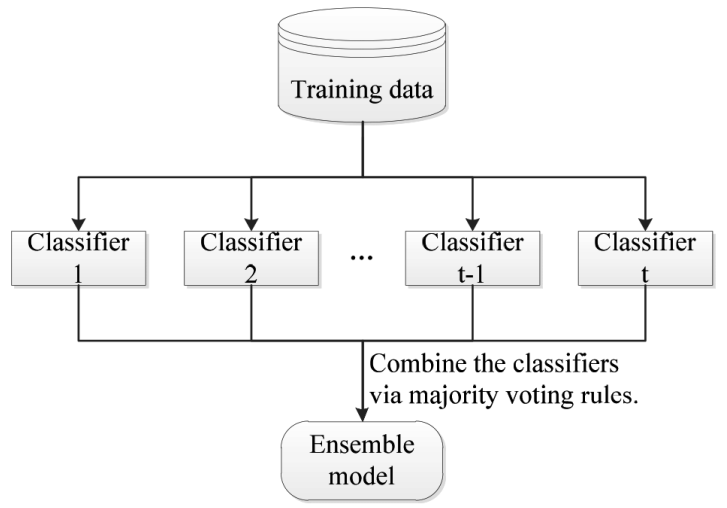

Figure 2. Ensemble method

\section{The prediction approach}

\subsection{Main causes for dispute}

Using the same data set, Table 3 summarizes the main causes of PPP disputes.

The events that trigger disputes differ across types of infrastructure projects. In municipal engineering (e.g. public gas supply, heat supply, wastewater treatment, and so forth) and cultural \& education PPP projects, government retracting the concession unilaterally is the main reason for dispute. On the one hand, the more unstable the political environment, the higher the probability of a dispute will be because the newly elected officials can have different ideas for the project, e.g. they have doubts about the project or are not interested in the project, and enact unilateral retracting (Guasch, 2004). On the other hand, after a couple of years of operation, the project, like the wastewater treatment capacity and gas supply capacity, couldn't satisfy the increasing demand. Due to the high degree of political independence, the government prefer to engage in skipping the renegotiation process and seeking the next private partner to build a new project to meet demand growth, thus compensating the previous private sector in a noncompetitive manner. Previous studies proved that public sectors take responsibility for unstable government risk and unilateral changes risk (Ke et al., 2010; Marques \& Berg, 2010, 2011). When unilateral changes happen, the inequitable risk 


\begin{tabular}{|c|c|c|c|c|c|c|c|c|c|c|c|c|}
\hline 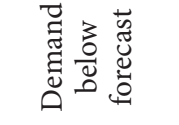 & in & $\wedge$ & $\sim$ & & & & & & & & $m$ & 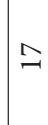 \\
\hline 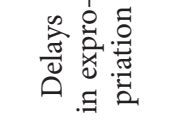 & $m$ & - & & & - & & & & & -1 & $\neg$ & 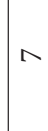 \\
\hline 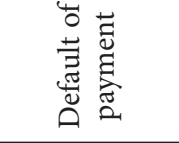 & $\stackrel{0}{\sim}$ & in & & & & & & & & & in & $\stackrel{\sim}{2}$ \\
\hline 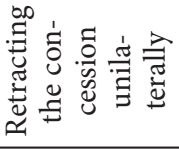 & 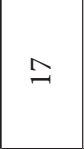 & $\infty$ & & - & $N$ & & & - & & & & શે \\
\hline 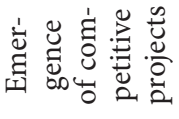 & $\wedge$ & - & & - & & - & & & & - & $N$ & $\stackrel{2}{=}$ \\
\hline 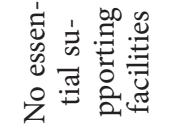 & $m$ & & $r$ & - & & - & & & $\sim$ & & & $\exists$ \\
\hline 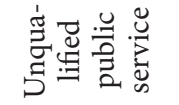 & 6 & - & & & & & & & & & $\neg$ & $\infty$ \\
\hline 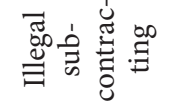 & 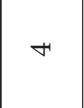 & - & & - & - & & - & & & & & $\infty$ \\
\hline 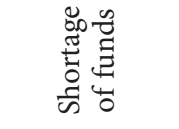 & $\simeq$ & $\sim$ & in & $\sim$ & - & - & $\neg$ & $\neg$ & & & $\rightarrow$ & $\stackrel{\sim}{2}$ \\
\hline 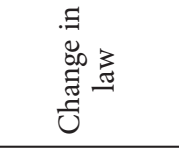 & 6 & $m$ & $m$ & $\neg$ & & & & & & & & $\stackrel{2}{2}$ \\
\hline 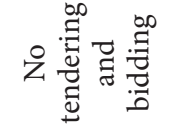 & 0 & - & - & $\rightarrow$ & - & & - & & & & $\sim$ & 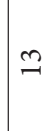 \\
\hline 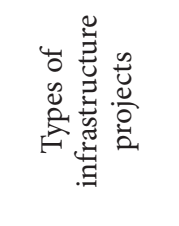 & 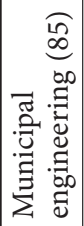 & 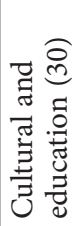 & 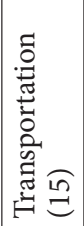 & 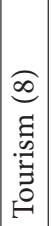 & 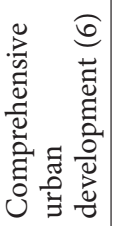 & 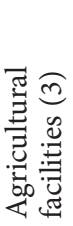 & 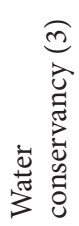 & 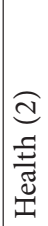 & 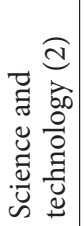 & 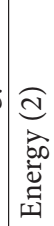 & 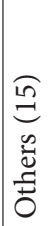 & 퓸 \\
\hline
\end{tabular}


allocation clauses (e.g. the cost of government default is low) in contract constitute one of the primary causes for triggering disputes.

In municipal engineering PPP project, default of payment ranks second important role in the causes of disputes. In government payment PPP project, public authorities are often in default of payment (e.g. wastewater treatment fee). Generally, the government doesn't have a professional team to reasonably estimate the cost and market demand, therefore, a high profit tends to be promised to attract the private partner's investment when signing contracts. Once the project is operated, the costs are out of the expected standard, which will leave the government without enough money to cover the operating fees.

Shortage of funds is also a significant cause for PPP disputes and is the most relevant in municipal engineering and transportation PPP projects by far. Project construction has been suspended due to reasons attributable to the failure of raising money. Because the municipal engineering and transportation construction in China have the traits: the high cost of investment and long construction period, it is hard to ensure the efficient construction fund supply. Financial risk (shortage of funds) is a type of high risk in PPP model (Marques \& Berg, 2010, 2011). The risk matrix of the PPP contract and relevant researches show that financial risk is generally always allocated to the private sector (Almarri et al., 2019; Ke et al., 2010; Marques \& Berg, 2011). Therefore, in this situation, the public sector can claim compensation for financial losses (e.g. from construction delays and new tendering) and liquidated damages.

Demand below forecast is another typical factor (high risk) for PPP dispute, mainly in the cultural and education projects in China. When revenues are exclusively or largely dependent on user charges, uncertainty is extremely high (Dewulf \& Garvin, 2020). The most common example is the student dormitory PPP project. Due to China's population control policies, the number of students is gradually declining and dormitory occupancy rates are lower than expected. The same model is sometimes found with regard to municipal services, in terms of the variation of passengers in municipal mass transit. When the revenues are below the forecasts, the initial assumptions of the annual investment recovery and payback period change, leading the private partner to ask for economic compensation or an extension of the concession period. Ke et al. (2010) illustrated that the demand (consumption) risk is preferred to be borne by private sectors or to be shared by both public and private sectors in China; The private sectors in the U.K. are responsible for demand risk; On the contrary, the public authority should bear this risk in Greece. Marques \& Berg (2011) suggested the demand (consumption) risk is preferred to be shared between the public and private sectors. Either party of the contract couldn't deal with this type of risk solely. Therefore, it is not possible to transfer all demand (consumption) risk to the private partner. For demand (consumption) risk, which without prevailing preference, the allocations of it need to be considered carefully by public and private sectors. Under this circumstances, a deficient understanding or even a misunderstanding of the risk matrix of PPP project could result in dispute.

The other causes for dispute are less frequent: in a tourist project, due to change in the law, the charging of entrance fees of the tourist resort was not allowed anymore. Legal risks often have a seriously impact on project revenue. The risks related to legislation changes should be assigned to the public authority (Ke et al., 2010; Marques \& Berg, 2011). As a consequence, the private partner claimed to terminate the contract and asked for the return of investment and compensation for expected revenues. Emergence of competitive projects is 
the cause for dispute due to overlapping with a previous concession, especially in municipal engineering projects. If the private sectors don't have a good understanding of risk shared mechanism before signing the contract, it is likely to cause the lack of terms of commitment to ensure project uniqueness in contract. This is the departing point to the conflicts. Under the Chinese legal system, tendering and bidding must be held in PPP projects, otherwise, the contract shall be an invalid contract. The lack of essential supporting facilities means the postponement of the beginning of operations. For example, in a wastewater treatment plant project, the government didn't build the wastewater inlet pipe and standard water discharge pipe, which prevented the wastewater treatment plant from operating. For the lack of essential supporting facilities, it is also a risk without prevailing preference. In this situation, if there is no explicit provision for risk allocation in contract, it will cause dispute.

Illegal subcontracting, unqualified public service and delays in expropriation are three relatively inconspicuous factors for dispute. Previous researches showed that construction risk (illegal subcontracting) and operation risk (unqualified public service) should be transferred to the private sector (Ke et al., 2010; Marques \& Berg, 2011). The facts also proved that these risks are allocated to the private sector in the contract. Illegal subcontracting shall be deemed as substantial breach of the PPP contract, therefore, the public authority has the legal right to terminate the contract. Additionally, the public services (e.g. water quality) provided by the private partner must be fully in accordance with the contract, otherwise, the government can claim compensation, or even terminate the contract. "Delays in expropriation" risk was assigned to the public authority with an obvious reason that Chinese government is responsible for this task. The government has the obligation to deliver the necessary land for the construction to the private partner on the date specified in the contract. Delays in expropriation will trigger claim of compensation for financial and revenue losses (from construction delays and postponement of operations).

As in agriculture, water conservancy, health, science sectors, the energy sector have not been significantly affected by disputes. Out of the 8,921 PPP projects in China, few public construction has focused on agricultural facilities (73), water conservancy (372), health (257), science (133), and energy facilities (108) (China Public Private Partnerships Center, 2019). Hence, the types of the disputes in these projects are not well known at this date.

A deficient understanding of the risk matrix of PPP project may result an inequitable assignment of risks in contract, then the inequitable assignment of risks may lead to disputes between public and private sectors (Zhang et al., 2019). Ke et al. (2010) suggested that, in the beginning of the public tender stage, government should state its risk sharing scheme. After assessing the scheme carefully, private sectors would propose a bidding price based on their capability of bearing these risks (Ke et al., 2010). A clear understanding of the risk matrix of PPP project will help reduce the probability of future disputes or mitigate the impact of a dispute.

\subsection{Main results of disputes}

For the same type of disputes, although the plaintiff's claims may differ in concrete details, most of them have a lot of features in common. After a detailed analysis for each of the cases, the plaintiff's claims and their respective court's judgment were extracted from the database. A table of the results is shown as Table 4. 
Table 4. Main results of disputes

\begin{tabular}{|c|c|c|}
\hline Dispute & Plaintiff's claim & Court's judgment \\
\hline $\begin{array}{l}\text { No } \\
\text { tendering } \\
\text { and bidding } \\
\text { (13) }\end{array}$ & $\begin{array}{l}\text { The private sector asked for the return of } \\
\text { investment, demanding compensation for } \\
\text { interest on investment and liquidated damages. }\end{array}$ & $\begin{array}{l}\text { Rejected } \\
\text { The PPP contract was confirmed } \\
\text { as invalid. Both parties bear losses } \\
\text { according to their own faults. }\end{array}$ \\
\hline $\begin{array}{l}\text { Change in } \\
\text { law (13) }\end{array}$ & $\begin{array}{l}\text { The private sector claimed to terminate the } \\
\text { contract and asked for the return of investment, } \\
\text { demanding compensation for interest on } \\
\text { investment and expected revenues. }\end{array}$ & $\begin{array}{l}\text { Provision of clauses in the contract } \\
\text { for compensation of expected } \\
\text { revenues. } \\
\text { If yes, supported (3) } \\
\text { If no, partly supported (10) }\end{array}$ \\
\hline $\begin{array}{l}\text { Shortage of } \\
\text { funds (26) }\end{array}$ & $\begin{array}{l}\text { The public authority claimed to: (1) terminate } \\
\text { the contract, demanding compensation for } \\
\text { financial losses (from construction delays } \\
\text { and new tendering) and liquidated damages; } \\
\text { (2) settle the project payment based on the } \\
\text { completed construction project, then the } \\
\text { private sector evacuate the construction site. }\end{array}$ & Supported \\
\hline $\begin{array}{l}\text { Illegal sub- } \\
\text { contracting } \\
(8)\end{array}$ & $\begin{array}{l}\text { The public authority claimed to: (1) terminate } \\
\text { the contract, demanding compensation for } \\
\text { financial losses (from construction delays } \\
\text { and new tendering) and liquidated damages; } \\
\text { (2) settle the project payment based on the } \\
\text { completed construction project, then the } \\
\text { private sector evacuate the construction site. }\end{array}$ & Supported \\
\hline $\begin{array}{l}\text { Unqualified } \\
\text { public } \\
\text { service (8) }\end{array}$ & $\begin{array}{l}\text { The public authority claimed to terminate } \\
\text { the contract, demanding compensation for } \\
\text { financial losses (from unqualified public service } \\
\text { and new tendering) and liquidated damages. }\end{array}$ & Supported \\
\hline $\begin{array}{l}\text { No essential } \\
\text { supporting } \\
\text { facilities } \\
\text { (11) }\end{array}$ & $\begin{array}{l}\text { The private sector claimed to terminate the } \\
\text { contract and asked for the return of investment, } \\
\text { demanding compensation for interest on } \\
\text { investment and liquidated damages. }\end{array}$ & $\begin{array}{l}\text { Provision of clauses in the contract } \\
\text { for public sector's obligation to } \\
\text { construct supporting facilities. } \\
\text { If yes, supported ( } 7 \text { ) } \\
\text { If no, rejected (4) }\end{array}$ \\
\hline $\begin{array}{l}\text { Emergence } \\
\text { of } \\
\text { competitive } \\
\text { projects (13) }\end{array}$ & $\begin{array}{l}\text { The private sector claimed to terminate the } \\
\text { contract and asked for the return of investment, } \\
\text { demanding compensation for interest on } \\
\text { investment, expected revenues and liquidated } \\
\text { damages. }\end{array}$ & $\begin{array}{l}\text { Provision of clauses in the contract } \\
\text { for exclusion of competitive } \\
\text { projects. } \\
\text { If no, rejected (7) } \\
\text { Provision of clauses in the contract } \\
\text { for compensation of expected } \\
\text { revenues. } \\
\text { If yes, supported (3) } \\
\text { If no, partly supported (3) }\end{array}$ \\
\hline $\begin{array}{l}\text { Retracting } \\
\text { the } \\
\text { concession } \\
\text { unilaterally } \\
(29)\end{array}$ & $\begin{array}{l}\text { The private sector requested to confirm the } \\
\text { administrative action was illegal and continue } \\
\text { to perform the contract. }\end{array}$ & $\begin{array}{l}\text { The new concessionaire have } \\
\text { completed the construction of the } \\
\text { new project or put it into operation. } \\
\text { If no, supported (22) } \\
\text { If yes, partly supported ( } 7 \text { ) }\end{array}$ \\
\hline $\begin{array}{l}\text { Default of } \\
\text { payment } \\
(26)\end{array}$ & $\begin{array}{l}\text { The private sector demanded payment of } \\
\text { arrears, interest on arrears and liquidated } \\
\text { damages for deferred payment. }\end{array}$ & Supported \\
\hline
\end{tabular}


End of Table 4

\begin{tabular}{|l|l|l|}
\hline \multicolumn{1}{|c|}{ Dispute } & \multicolumn{1}{|c|}{ Plaintiff's claim } & \multicolumn{1}{c|}{ Court's judgment } \\
\hline $\begin{array}{l}\text { Delays } \\
\text { in expro- } \\
\text { priation (7) }\end{array}$ & $\begin{array}{l}\text { The private sector asked for remedies (e.g. land } \\
\text { replacement for the project), compensation for } \\
\text { financial and revenue losses (from construction } \\
\text { delays and postponement of operation) and } \\
\text { liquidated damages. }\end{array}$ & Supported \\
\hline $\begin{array}{l}\text { Demand } \\
\text { below } \\
\text { forecast (17) }\end{array}$ & $\begin{array}{l}\text { The private sector asked for compensation } \\
\text { for insufficient demand, or an extraordinary } \\
\text { extension in concession duration. }\end{array}$ & $\begin{array}{l}\text { Provision of clauses in the contract } \\
\text { for compensation of minimum } \\
\text { limit demand. } \\
\text { If yes, supported (10) } \\
\text { If no, rejected (7) }\end{array}$ \\
\hline
\end{tabular}

\subsection{How legal factors influence the litigation outcomes}

Based on the plaintiff's claim and the court's decision (refer to Table 4), Figure 3 presents the relative importance of the 17 factors in the prediction process, and how different legal factors lead to different litigation outcomes.

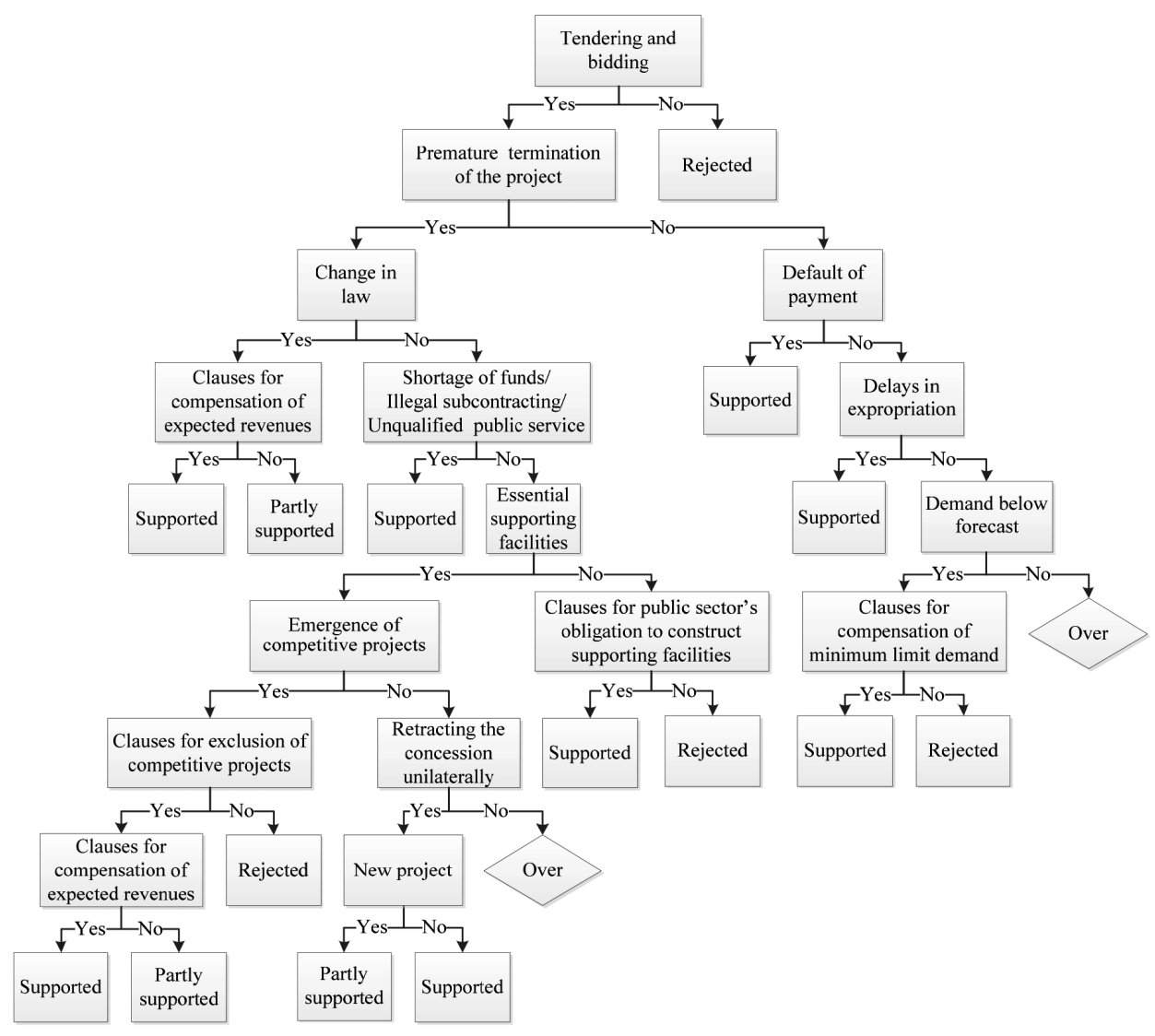

Figure 3. From legal factors to the litigation outcomes 
When making a judgment, the validity of a contract is the primary concern of the judges. As per clause 52 of "The PRC Contract Law" and clause 8 of "Administration of Concession Procedures", PPP projects must be awarded through public tender method. The purpose of public tenders is to ensure that competition will allow governments to select the most suitable private partner. If the above-mentioned legal procedures are failed to perform by the parties, the contract shall be an invalid contract and have no legal effect. Both parties to the contract should bear corresponding losses according to their own faults (signing contract without tendering and bidding), resulting the private sector's claim was rejected. Obviously, in these cases, the government doesn't need to pay compensation and liquidated damages, therefore, the private sector suffers enormous economic losses. To avoid this type of dispute, the private sectors must strictly follow the bidding process and sign the contract after winning the bid.

For projects that are terminated prematurely, change in law is an event outside their both responsibilities, that needs to be considered firstly. In this circumstance, neither party is liable for breach of contract, therefore, there is no compensation for liquidated damages. Due to change in the law, it is no longer legal to continue performing the contract, so the private investors couldn't recoup their investment by continuing to operate PPP projects. The request for the return of investment and compensation of interest on investment shall be supported by the court. However, not all contracts provided express provision for compensation of expected revenues. Among the 13 cases (Table 5), only 3 claims were supported, the remaining 10 claims couldn't be supported due to the lack of provisions of compensation for expected revenues. When investing in PPP projects, the investors must pay attention to explicitly stipulate the compensation for expected revenues in the contract to prevent the revenue losses.

If the early termination of the project is not caused by the change in law, then the judges will deliberate whether any material breach of the contract is committed. Due to the fact that the private sectors seriously violate the stipulations of the contract (shortage of funds, illegal subcontracting and unqualified public service), the governments have the right to terminate the contract. Thereby, the governments won all these lawsuits against the private partners for compensation of financial losses (from construction delays, unqualified public service and new tendering) and liquidated damages. The outcome of these cases indicates that in order to prevent the project from failing, the government need to strictly examine the financial and credit information of the private partner in the bidding stage.

Without essential supporting facilities, the projects couldn't begin to come into service after the completion of construction. If the government fails to fulfill the obligation (constructing the essential supporting facilities), the private partner shall have the right to terminate the contract in accordance with the provisions of the contract as well as to ask for the return of investment and liquidated damages. If the clauses for public sector's obligation to construct supporting facilities are not provided in the contract, the plaintiff's claim shall be rejected. For example, the Jiangsu Provincial Government tried to build a business administration MIS (Management Information System) that providing information services for enterprises, and it could connect the network with Tax, Customs and Banks, so as to realize information sharing in multiple fields (i.e. industry cooperation network). After the business administration MIS was finished by the private sector, it couldn't connect with other networks due to the profession CA (certification authority) system construction was not achieved, as a result, 
there was little room left for a return on private's investment. In the aforementioned case of the wastewater treatment plant, the contract specified the government's responsibilities for construction the wastewater inlet pipe and standard water discharge pipe. However, in this case, there was no clauses in the contract for government's obligation to build the profession CA system. Finally, the private sector lost the lawsuit.

Emergence of competitive project, means the concession is awarded to a third party by the government overlaps with the previous concession. The existence of competitive project is sufficient to undermine the protection of the previous private sector's revenues during the operation process. In other words, emergence of competitive project will result in the consequence that the private enterprise's investment couldn't be recovered on schedule. In this situation, whether the government violates the contract can not be determined directly by the court, and further verification is needed to check if there is express condition in the contract for exclusion of competitive projects. If the government explicitly guarantees the unique of the project in a specific region in the contract, the behavior of granting the concession to a third party shall be deemed as substantial breach of the contract, therefore, the private sector's request to terminate the contract and ask for the return of investment shall be supported by the court. For future profits compensation, it depends on the clauses for compensation of expected revenues in the contract. For private sectors, to protect their operation revenues from being carved up, the clauses for exclusion of competitive projects should be stipulated explicitly in the contract.

If the early termination of the project is not caused by the above factors, in consideration of the database of 171 cases in this study, the last factor that triggers the premature termination of the project is retracting the concession unilaterally by the government. Generally, it is very likely that the private partner will go to court to attempt to recapture the concession. By the time of the case trial stage, if the third party (new concessionaire) have constructed the new project or put it into operation, the cancellation of the administrative action (retracting the concession) will bring losses to the public interest (e.g. the new project allows people to enjoy more advanced public services). As per clause 74 of "The PRC Administrative Procedure Law", administrative actions that damage the reliance interest shall be canceled in accordance with the law, however, if the cancellation will cause great damage to the national, social and public interests, then the court shall make a decision that the administrative action is illegal and instruct the government to adopt remedies. Thus, from the perspective of protecting the public interest, the private sector's claim to continue to perform the contract cannot be supported by the Chinese courts. To reduce the risk, the clauses for conditions and procedures of retracting the concession unilaterally should be stipulated as specific as possible in the contract. If termination clauses increase the default cost, e.g. by determining that all future profits gained until the end of the contract should be paid if the concession is retracted unilaterally, the government does not enjoy the real possibility of capturing the concessions if the due date is still remote (Cruz \& Marques, 2013b).

For projects that are not terminated in advance, when predicting the outcome of this type of disputes, the first consideration is whether the parties have any breach of the contract. In government payment PPP projects, paying for public services is a contractual obligation of the government. If the government is in default of payment due to objective or subjective 
reasons, then the private sector has the right to demand payment of arrears, interest on arrears and liquidated damages for deferred payment.

In China's PPP projects, delivering the necessary land for the construction of the infrastructure to the private partner is the responsibility of the government. If the government fails to complete the expropriation on prespecified date in the contract, and still fails to perform the obligation or remedy such breach within the period of time that allowed for delayed performance, in such case the private sector shall be entitled to ask for remedies (e.g. land replacement for the project) and claim damages.

Project demand has a significant underlying degree of uncertainty in the long run, both economic fluctuations and policy adjustments can impact the demand. For another, the optimism bias is also a major issue that leads to deviation in demand forecasting (Cruz \& Marques, 2013b). If demand is lower than forecast (minimum limit demand), the revenues are not sufficient to cover operation costs and debt service, let alone investment recovery. As a consequence, the demand risk is enough to trigger the occurrence of a dispute. If the contract contains clauses for compensation of minimum limit demand, the private sector is entitled to ask for compensation for insufficient demand, or an extraordinary extension in concession duration. Whereas if the government never makes the commitment (compensation for insufficient demand) in contract, the court couldn't impose obligation on the government, although one may argue that the court's decision does not ensure the private enterprises' welfare. For the sake of a win-win PPP outcome and for sustainable development of PPP strategy, Vassallo (2006) demonstrated that the mechanisms for addressing demand variations should be included in the PPP agreement. Likewise, Cruz and Marques (2013b) argued that a detailed model is needed in contract to clarify each partner's responsibility in terms of demand risk. If there is a perfect allocation of demand (consumption) risk in the contract, it will be helpful in reducing the occurrence of dispute.

\section{Model implementation and results}

The above prediction approach explanation illustrates that these 17 legal factors are reliable in theory to predict the litigation outcomes of PPP disputes. Then the aforementioned nine machine learning models were developed to predict the litigation outcome of PPP project.

\subsection{Model implementation}

Python (version 3.6), a powerful object-oriented programming language, was used in this study for developing, training, and validating the models. To make the tool easier to implement and apply as a user-friendly tool, the model parameters were set to the default values in this study.

The previously described methodology were used to predict the litigation outcomes of PPP disputes on the basis of the 17 legal factors. Each factor has two options for its value, and the options were assigned different values 0 ; 1 . For example, considering the factor "Provision of clauses in the contract for compensation of minimum limit demand" has two options: yes and no. If the clauses of compensation of minimum limit demand are included 
in the PPP contract, the value is ' 0 ', and it will be ' 1 ' when these clauses are not included in the PPP contract.

\subsubsection{Performance evaluation}

To measure the classification and prediction performance of the trial runs of different models, evaluation indexes like accuracy, precision, recall, f-measure, mean square error (MSE) and kappa coefficient were commonly used (Chaphalkar et al., 2015; Chou \& Lin, 2013; Ferri et al., 2009; Kim, 2010; Mahfouz \& Kandil, 2012) in research.

Prediction accuracy, which is defined as the proportion of the number of cases that is accurately predicted relative to the total number of tested cases, is an important evaluation index to measure whether the model could make correct decisions.

Precision in this study is defined as the number of cases correctly predicted as belonging to the target class divided by the total number of cases recognized belonging to that class (i.e., the sum of cases that are correctly predicted and incorrectly predicted as belonging to the target class). For example, suppose the target class is "the claim was rejected", then of the $\mathrm{N} 1$ cases which outcome are identified as "the claim was rejected", N2 cases' outcome actually are "the claim was rejected", while the rest are not. This class precision is N2/N1.

Recall is defined as the fraction of the number of cases correctly predicted as belonging to a specific class to the total number of cases that actually belongs to this class (i.e., the sum of cases that are correctly predicted and cases that were not classified as this class but should have been). Taking the same example as above, suppose the target class is still "the claim was rejected", N2 is still the number of cases correctly identified as belonging to this class, N3 means the number of cases that should have been labeled as "the claim was rejected". This class recall is $\mathrm{N} 2 / \mathrm{N} 3$.

The F-Measure, which ranges from 0 to 1 (worst to best), is a synthetical evaluation index to evaluate the overall performance of precision and recall. F-Measure is the harmonic mean of the precision and recall (Equation (1)). For more illustration, if the value of recall is very high while with a very low value of precision in a database, then the F-Measure as a tradeoff between precision and recall needs to be considered necessarily:

$$
F-\text { Measure }=\frac{2 \text { Precision } \times \text { Recall }}{\text { Precision }+ \text { Recall }} .
$$

Mean square error (MSE) in this study can be used to measure the difference between the models output and the actual output, but it could not reflect whether the output of the model is consistent with the actual output (Chaphalkar et al., 2015). Kappa coefficient helps in consistency checking. The Kappa coefficient ranges from -1.0 to +1.0 , with a value +1.0 meaning a high degree of consistency, -1.0 meaning complete inconsistency and 0 indicating consistency that is only by chance.

\subsubsection{K-fold cross-validation}

Several studies obtained better prediction results in construction litigation prediction when 90\% cases were considered for training and the remaining 10\% for testing (Arditi \& Pulket, 2005; Mahfouz \& Kandil, 2012). In this study, therefore, out of the total 221 cases in the 
database, 199 cases (90\%) were randomly selected for model training and 22 cases (10\%) were used for testing purpose.

The theory behind the training and validation of the models is $\mathrm{k}$-fold cross-validation, sometimes called rotation estimation (Kohavi, 1995; Shawe-Taylor \& Cristianini, 2000). In $\mathrm{k}$-fold cross-validation, the data set is randomly divided into $\mathrm{k}$ subsets with equal size. Of the $\mathrm{k}$ subsets, the model is trained over the $\mathrm{k}-1$ subsets and tested over the remaining 1 subset. This cross-validation manner is repeated $\mathrm{k}$ times until each of the subsets is used as testing data. After the process is finished, the $\mathrm{k}$ predicting results will be averaged to obtain the final prediction. The obvious advantage of this approach is that all cases could be trained and tested (Mahfouz \& Kandil, 2012). Kohavi's (1995) research showed that when the kalue is 10 , the variance is optimal. Thus, a 10 -fold cross-validation was performed in this study.

\subsection{Results and discussion}

The performances of the aforementioned nine ML models are summarized in Table 5. The GBDT attained the highest accuracy of $96.06 \%$, whereas the SVM attained lowest accuracy of $69.87 \%$. In terms of precision, GBDT ranked first (96.44\%) followed by KNN (94.96\%) and MLP (92.77\%). The GBDT model achieved the best performance (96.06\%) in recall. Moreover, the highest F-measure of $95.75 \%$ and highest kappa of 0.92 were also attained using GBDT model. Therefore, it is manifestly clear that GBDT was the best single model with respect to all evaluation indexes. Recent researches also obtained an excellent prediction accuracy in the area of business and economics by using the GBDT model. J. Zhou et al. (2019) developed three decision tree-based models (including GBDT) to predict the default probability of each individual loan in a P2P network loan platform, and achieved desirable prediction results. In an attempt to forecast the daily changes of stock indices, six ML models were trained by Zhou, F. et al. (2019) and the GBDT model outperformed (precision was $95 \%$ in one of the stock markets) the other five models in predictive performance.

Table 5. Results of ML models

\begin{tabular}{|l|c|c|c|c|c|c|}
\hline Model & $\begin{array}{c}\text { Accuracy } \\
(\%)\end{array}$ & $\begin{array}{c}\text { Precision } \\
(\%)\end{array}$ & $\begin{array}{c}\text { Recall } \\
(\%)\end{array}$ & $\begin{array}{c}\text { F-measure } \\
(\%)\end{array}$ & kappa & MSE \\
\hline GBDT & $96.06(1)$ & $96.44(1)$ & $96.06(1)$ & $95.75(1)$ & $0.9200(1)$ & $0.0436(1)$ \\
\hline KNN & $94.36(2)$ & $94.96(2)$ & $94.36(2)$ & $94.02(2)$ & $0.8861(2)$ & $0.0600(2)$ \\
\hline MLP & $92.19(3)$ & $92.77(3)$ & $92.19(3)$ & $91.56(3)$ & $0.8396(3)$ & $0.0781(3)$ \\
\hline DT & 91.05 & 91.79 & 91.05 & 90.06 & 0.8154 & 0.0911 \\
\hline RF & 89.53 & 90.71 & 89.53 & 88.63 & 0.7796 & 0.1083 \\
\hline LR & 85.27 & 85.16 & 85.27 & 82.82 & 0.6722 & 0.1473 \\
\hline XGBoost & 82.97 & 83.31 & 82.97 & 81.15 & 0.6359 & 0.1811 \\
\hline AdaBoost & 70.77 & 69.60 & 70.77 & 66.72 & 0.3657 & 0.3189 \\
\hline SVM & 69.87 & 60.77 & 69.87 & 60.36 & 0.2236 & 0.3013 \\
\hline
\end{tabular}

Note: (1)-(3) means performance ranking. 
According to the predictive performance, the top three models were GBDT, KNN and MLP. Then, the majority voting method was used to combine the three models and the ensemble model output is shown in Table 6. It shows that the performance of the ensemble model was improved compared with the above three individual models (refer to Table 5) except the MSE. The ensemble model (96.42\%) achieved an increase in accuracy of $0.36 \%$. Interestingly, after model integration, the ensemble model attained a MSE of 0.0443 (refer to Table 6), which is worse than 0.0436 (the best MSE derived from GBDT in Table 5).

Table 6. Results of ensemble model

\begin{tabular}{|l|c|c|c|c|c|c|}
\hline $\begin{array}{c}\text { Ensemble } \\
\text { model }\end{array}$ & $\begin{array}{c}\text { Accuracy } \\
(\%)\end{array}$ & $\begin{array}{c}\text { Precision } \\
(\%)\end{array}$ & $\begin{array}{c}\text { Recall } \\
(\%)\end{array}$ & $\begin{array}{c}\text { F-measure } \\
(\%)\end{array}$ & kappa & MSE \\
\hline $\begin{array}{l}\text { GBDT + } \\
\text { KNN + MLP }\end{array}$ & 96.42 & 96.66 & 96.38 & 96.03 & 0.9243 & 0.0443 \\
\hline
\end{tabular}

In conclusion, of the nine models, GBDT was the best single model for prediction of litigation outcome in China's PPP project disputes between public authority and private partner, whereas SVM was the worst model in all evaluation indexes. Notably, the predictive performance of the ensemble model was better than three single models. It appears that the idea of an ensemble model that makes use of combinations of various models is more likely to obtain a better prediction performance.

\section{Conclusions}

The evidence from China's PPP litigation cases supports the concern that disputes are a major problem in PPP development. Among the 171 litigation cases, the number of cases in municipal engineering (85) and cultural and education (30) is relatively high, however, the projects in agriculture (3), water conservancy (3), health (2), science (2) and energy (2) sectors have low rates of dispute. Through case studies, the information on the events that lead to PPP dispute is provided in this study. Three of the top dispute triggers are retracting the concession unilaterally (29), shortage of funds (26) and default of payment (26). Illegal subcontracting (8), unqualified public service provided by private sector (8) and delays in expropriation (7) are less frequent in determining the occurrence of a dispute.

Based on the causes of PPP disputes and their respective litigation outcomes, the study identified 17 factors, which influence the decision-making of the judges in the process of judgment. Using the 17 legal factors, a flow chart was drawn to illustrate how the legal factors influence the litigation outcomes. To validate the reliability of the above explanation, nine ML models were developed and three best performed models were combined to predict the dispute litigation outcome. The high accuracy of $96.42 \%$ obtained by the ensemble model $(\mathrm{GBDT}+\mathrm{KNN}+\mathrm{MLP})$ proved that these 17 legal factors were appropriate to explain and predict the litigation outcomes in PPP disputes.

The contract should contain "rules" for managing each of the aforementioned events and guiding how to resolve them. Some crucial contract clauses are frequently used in courts to support the judgments, such as the clauses for compensation of expected revenues, clauses for 
compensation of minimum limit demand and clauses for exclusion of competitive projects. The absence of these crucial clauses in contract will result in the rejection of the plaintiff's claim. The contract theory enforces the idea that an unfair risk-sharing agreement will tend to be disputed more often. There is clearly a need for both parties to sign a complete, detailed and fair PPP contract to avoid suffering huge losses.

Apart from the problems related to incompleteness of contracts, a detailed monitoring system or rules of the contracts should be formulated to avoid opportunistic behaviors. In the meantime, perhaps both parties of the contract will face penalties when contract noncompliance happens. Finally, in the actual practice of PPP projects, what China needs is not only a complete contract and monitoring system of the contract but, more importantly, the spirit of contract. Once the contract is established, both government and private partners need to strictly obey the contract and fulfill their obligations.

The findings of this study provide decision-support information for managers. Decision makers can assess the legal consequences of their dispute resolution strategy in advance to decide whether to resolve the dispute through litigation. The proposed ensemble model may be consulted by public authority and private partner, which will help save time and money spent in consulting with professional lawyers or experts in PPP projects. It could also be consulted by negotiators, mediators, arbitrators and judges to facilitate their decision-making and improve their work efficiency.

It is important to acknowledge a limitation of this study. 171 cases studied do not fully mirror all categories of disputes in PPP projects. In China, the PPP investment model began to be widely promoted and applied since 2013. Many PPP projects have just entered the preparation or construction stage, and don't face the stage of concentrated outbreak of disputes. The limited number of litigation cases make it infeasible to identify which model is needed to predict which dispute category at which phases. With the increase of the cases in the future, potential research is to classify PPP project disputes at different phases of the PPP project life cycle.

\section{Acknowledgements}

The authors would like to thank the experts for their precious advice. The authors also want to express the gratitude to the lawyers from Da Du Law Firm who helped us during the case selection process.

\section{Funding}

This work was supported by the National Natural Science Foundation of China (71841022), China Scholarship Council Joint PhD Project (201707090017), and Beijing Social Science Foundation (17GLB018).

\section{Disclosure statement}

All the authors have no conflict of interests. 


\section{References}

Albert, J. M., Durepos, G., \& Wiebe, E. (2010). Encyclopedia of case study research. Sage.

Alexandre, L. A., Campilho, A. C., \& Kamel, M. (2001). On combining classifiers using sum and product rules. Pattern Recognition Letters, 22(12), 1283-1289. https://doi.org/10.1016/S0167-8655(01)00073-3

Almarri, K., Alzahrani, S., \& Boussabaine, H. (2019). An evaluation of the impact of risk cost on risk allocation in public private partnership projects. Engineering, Construction and Architectural Management, 26(8), 1696-1711. https://doi.org/10.1108/ECAM-04-2018-0177

Arditi, D., Oksay, F., \& Tokdemir, O. (1998). Predicting the outcomes of construction litigation using neural networks. Computer-Aided Civil and Infrastructure Engineering, 13(2), 75-81. https://doi.org/10.1111/0885-9507.00087

Arditi, D., \& Pulket, T. (2005). Predicting the outcome of construction litigation using boosted decision trees. Journal of Computing in Civil Engineering, 19(4), 387-393. https://doi.org/10.1061/(ASCE)0887-3801(2005)19:4(387)

Arditi, D., \& Pulket, T. (2010). Predicting the outcome of construction litigation using an integrated artificial intelligence model. Journal of Computing in Civil Engineering, 24(1), 73-80. https://doi.org/10.1061/(ASCE)0887-3801(2010)24:1(73)

Arditi, D., \& Tokdemir, O. (1999). Using case-based reasoning to predict the outcome of construction litigation. Computer-Aided Civil and Infrastructure Engineering, 14(6), 385-393. https://doi.org/10.1111/0885-9507.00157

Carrillo, P., Robinson, H., Foale, P., Anumba, C., \& Bouchlaghem, D. (2008). Participation, barriers, and opportunities in PFI: The United Kingdom experience. Journal of Management in Engineering, 24(3), 138-145. https://doi.org/10.1061/(ASCE)0742-597X(2008)24:3(138)

Chan, A. P. C., Chan, D. W. M., \& Ho, K. S. K. (2003). Partnering in construction: Critical study of problems for implementation. Journal of Management in Engineering, 19(3), 126-135. https://doi.org/10.1061/(asce)0742-597x(2003)19:3(126)

Chan, A. P. C., Lam, P., Wen, Y., Ameyaw, E., Wang, S. Q., \& Ke, Y. (2015). Cross-sectional analysis of critical risk factors for PPP water projects in China. Journal of Infrastructure Systems, 21(1), 04014031. https://doi.org/10.1061/(ASCE)IS.1943-555X.0000214

Chaphalkar, N. B., Iyer, K.C., \& Patil, S. K. (2015). Prediction of outcome of construction dispute claims using multilayer perceptron neural network model. International Journal of Project Management, 33(8), 1827-1835. https://doi.org/10.1016/j.ijproman.2015.09.002

Chau, K. W. (2007). Application of a PSO-based neural network in analysis of outcomes of construction claims. Automation in Construction, 16(5), 642-646. https://doi.org/10.1016/j.autcon.2006.11.008

Cheng, Z., Ke, Y., Lin, J., Yang, Z., \& Cai, J. (2016). Spatio-temporal dynamics of public private partnership projects in China. International Journal of Project management, 34(7), 1242-1251. https://doi.org/10.1016/j.ijproman.2016.05.006

Cheung, S. O., Suen, H. C. H., \& Lam, T. I. (2002). Fundamentals of alternative dispute resolution processes in construction. Journal of Construction Engineering and Management, 128(5), 409-417. https://doi.org/10.1061/(asce)0733-9364(2002)128:5(409)

Cheung, S. O., Tam, C. M., \& Harris, F. C. (2000). Project dispute resolution satisfaction classification through neural network. Journal of Management in Engineering, 16(1), 70-79. https://doi.org/10.1061/(ASCE)0742-597X(2000)16:1(70)

Cheung, S. O., Yiu, T. W., \& Chan, H. W. (2010). Exploring the potential for predicting project dispute resolution satisfaction using logistic regression. Journal of Construction Engineering and Management, 136(5), 508-517. https://doi.org/10.1061/(ASCE)CO.1943-7862.0000157 
China Judgements Online. (2018). Retrieved October 31, 2018, from http://wenshu.court.gov.cn/

China Public Private Partnerships Center. (2019). National PPP Information Platform. Retrieved June 30, 2019, from https://www.cpppc.org:8082/inforpublic/homepage.html\#/projectPublic

Chou, J. S., \& Lin, C. (2013). Predicting disputes in public-private partnership projects: Classification and ensemble models. Journal of Computing in Civil Engineering, 27(1), 51-60. https://doi.org/10.1061/(ASCE)CP.1943-5487.0000197

Cruz, C. O., \& Marques, R. C. (2013a). Exogenous determinants for renegotiating public infrastructure concessions: Evidence from Portugal. Journal of Construction Engineering and Management, 139(9), 1082-1090. https://doi.org/10.1061/(ASCE)CO.1943-7862.0000710

Cruz, C. O., \& Marques, R. C. (2013b). Endogenous determinants for renegotiating concessions: Evidence from local infrastructure. Local Government Studies, 39(3), 352-374. https://doi.org/10.1080/03003930.2013.783476

Dansoh, A., Frimpong, S., Ampratwum, G., Oppong, G. D., \& Osei-Kyei, R. (2020). Exploring the role of traditional authorities in managing the public as stakeholders on PPP projects: a case study. International Journal of Construction Management, 20(6), 628-641. https://doi.org/10.1080/15623599.2020.1725722

Dewulf, G., \& Garvin, M. J. (2020). Responsive governance in PPP projects to manage uncertainty. Construction Management and Economics, 38(4), 1-15. https://doi.org/10.1080/01446193.2019.1618478

Ding, J. Y., Jia, J. Y., Jin, C. H., \& Wang, N. (2018). An innovative method for project transaction mode design based on case-based reasoning: A Chinese case study. Sustainability, 10(11), 4127. https://doi.org/10.3390/su10114127

Dixon, T., Pottinger, G., \& Jordan, A. (2005). Lessons from the private finance initiative in the UK: Benefits, problems and critical success factors. Journal of Property Investment \& Finance, 23(5), 412-423. https://doi.org/10.1108/14635780510616016

Doğan, S. Z., Arditi, D., \& Gunaydin, H. M. (2008). Using decision trees for determining attribute weights in a case-based model of early cost prediction. Journal of Construction Engineering and Management, 134(2), 146-152. https://doi.org/10.1061/(ASCE)0733-9364(2008)134:2(146)

Feng, K., Xiong, W., Wang, S., Wu, C. \& Xue, Y. (2017). Optimizing an equity capital structure model for public-private partnership projects involved with public funds. Journal of Construction Engineering and Management, 143(9), 04017067. https://doi.org/10.1061/(ASCE)CO.1943-7862.0001349

Ferri, C., Hernández-Orallo, J., \& Modroiu, R. (2009). An experimental comparison of performance measures for classification. Pattern Recognition Letters, 30(1), 27-38. https://doi.org/10.1016/j.patrec.2008.08.010

Guasch, J. L. (2004). Renegotiating infrastructure concessions: Doing it right. World Bank Institute. https://doi.org/10.1596/0-8213-5792-1

Haugen, T., \& Singh, A. (2015). Dispute resolution strategy selection. Journal of Legal Affairs and Dispute Resolution in Engineering and Construction, 7(3), 05014004.

https://doi.org/10.1061/(ASCE)LA.1943-4170.0000160

Ke, Y. J., Wang, S. Q., \& Chan, A. P. C. (2010). Risk allocation in public-private partnership infrastructure projects: Comparative study. Journal of Infrastructure Systems, 16(4), 343-351. https://doi.org/10.1061/(ASCE)IS.1943-555X.0000030

Kim, Y. S. (2010). Performance evaluation for classification methods: A comparative simulation study. Expert Systems with Applications, 37(3), 2292-2306. https://doi.org/10.1016/j.eswa.2009.07.043

Kohavi, R. (1995). A study of cross-validation and bootstrap for accuracy estimation and model selection. In 14th International Joint Conference on Artificial Intelligence (pp. 1137-1143). San Francisco, California, USA. 
Kwon, N., Park, M., Lee, H. S., Ahn, J., \& Kim, S. (2017). Construction noise prediction model based on case-based reasoning in the preconstruction phase. Journal of Construction Engineering and Management, 143(6), 04017008. https://doi.org/10.1061/(ASCE)CO.1943-7862.0001291

Lee, M. C. (2009). Using support vector machine with a hybrid feature selection method to the stock trend prediction. Expert Systems with Applications, 36(8), 10896-10904. https://doi.org/10.1016/j.eswa.2009.02.038

Lin, J. Y., Cheng, C. T., \& Chau, K. W. (2006). Using support vector machines for long-term discharge prediction. Hydrological Sciences Journal, 51(4), 599-612. https://doi.org/10.1623/hysj.51.4.599

Mahfouz, T., \& Kandil, A. (2009). Factors affecting litigation outcomes of differing site conditions (DSC) disputes: A logistic regression model (LRM). In 2009 Construction Research Congress (pp. 239-248). ASCE, Reston, Virginia. USA. https://doi.org/10.1061/41020(339)25

Mahfouz, T., \& Kandil, A. (2012). Litigation outcome prediction of differing site condition disputes through machine learning models. Journal of Computing in Civil Engineering, 26(3), 298-308. https://doi.org/10.1061/(ASCE)CP.1943-5487.0000148

Marques, R. C. (2018). Is arbitration the right way to settle conflicts in PPP arrangements? Journal of Management in Engineering, 34(1), 05017007. https://doi.org/10.1061/(ASCE)ME.1943-5479.0000564

Marques, R. C., \& Berg, S. (2010). Revisiting the strengths and limitations of regulatory contracts in infrastructure industries. Journal of Infrastructure Systems, 16(4), 334-342. https://doi.org/10.1061/(ASCE)IS.1943-555X.0000029

Marques, R. C., \& Berg, S. (2011). Risks, contracts, and private-sector participation in infrastructure. Journal of Construction Engineering and Management, 137(11), 925-932. https://doi.org/10.1061/(ASCE)CO.1943-7862.0000347

Mitropoulos, P., \& Howell, G. (2001). Model for understanding, preventing, and resolving project disputes. Journal of Construction Engineering and Management, 127(3), 223-231. https://doi.org/10.1061/(ASCE)0733-9364(2001)127:3(223)

Mustapha, I. B., \& Saeed, F. (2016). Bioactive molecule prediction using extreme gradient boosting. Molecules, 21(8), 983. https://doi.org/10.3390/molecules21080983

Opitz, D., \& Maclin, R. (1999). Popular ensemble methods: An empirical study. Journal of Artificial Intelligence Research, (11), 169-198. https://doi.org/10.1613/jair.614

Osei-Kyei, R., \& Chan, A. P. C. (2017). Empirical comparison of critical success factors for public-private partnerships in developing and developed countries: A case of Ghana and Hong Kong. Engineering, Construction and Architectural Management, 24(6), 1222-1245. https://doi.org/10.1108/ECAM-06-2016-0144

Osei-Kyei, R., Chan, A. P. C., Yu, Y., Chen, C., \& Dansoh, A. (2019). Root causes of conflict and conflict resolution mechanisms in public-private partnerships: Comparative study between Ghana and China. Cities, (87), 185-195. https://doi.org/10.1016/j.cities.2018.10.001

Pulket, T., \& Arditi, D. (2009). Universal prediction model for construction litigation. Journal of Computing in Civil Engineering, 23(3), 178-187. https://doi.org/10.1061/(ASCE)0887-3801(2009)23:3(178)

Robert, K. Y. (2014). Case study research: Design and methods (pp. 5-8). Sage.

Rogova, G. (1994). Combining the results of several neural network classifiers. Neural Networks, 7(5), 777-781. https://doi.org/10.1016/0893-6080(94)90099-X

Rokach, L. (2010). Ensemble-based classifiers. Artificial Intelligence Review, 33(1-2), 1-39. https://doi.org/10.1007/s10462-009-9124-7

Shawe-Taylor, J., \& Cristianini, N. (2000). Support vector machines and other kernel-based learning methods. Cambridge University Press. https://doi.org/10.1017/CBO9780511801389 
Steen, R. H. (1994). Five steps to resolving construction disputes-without litigation. Journal of Management in Engineering, 10(4), 19-21. https://doi.org/10.1061/(ASCE)9742-597X(1994)10:4(19)

Treacy, T. B. (1995). Use of alternative dispute resolution in the construction industry. Journal of Management in Engineering, 11(1), 58-63. https://doi.org/10.1061/(ASCE)0742-597X(1995)11:1(58)

Vassallo, J. M. (2006). Traffic risk mitigation in highway concession projects: the experience of Chile. Journal of Transport Economics and Policy, 40(3), 359-381. https://www.jstor.org/stable/20053991

Wang, J. D., Li, P., Ran, R., Che, Y. B., \& Zhou, Y. (2018). A short-term photovoltaic power prediction model based on the gradient boost decision tree. Applied Sciences, 8(5), 689. https://doi.org/10.3390/app8050689

Wu, X. H., Fu, H. J., Tian, X. Y., \& Sun, J. (2017). Prediction of pork storage time using Fourier transform near infrared spectroscopy and Adaboost-ULDA. Journal of Food Process Engineering, 40(6), 12566. https://doi.org/10.1111/jfpe.12566

Zhang, L. H., Fenn, P., \& Fu, Y. C. (2019). To insist or to concede? Contractors' behavioural strategies when handling disputed claims. Engineering, Construction and Architectural Management, 26(3), 424-443. https://doi.org/10.1108/ECAM-05-2018-0219

Zhou, F., Zhang, Q., Sornette, D., \& Jiang, L. (2019). Cascading logistic regression onto gradient boosted decision trees for forecasting and trading stock indices. Applied Soft Computing Journal, 84, 105747. https://doi.org/10.1016/j.asoc.2019.105747

Zhou, J., Li, W., Wang, J. X., Ding, S., \& Xia, C. Y. (2019). Default prediction in P2P lending from highdimensional data based on machine learning. Physica A: Statistical Mechanics and its Applications, 534, 122370. https://doi.org/10.1016/j.physa.2019.122370 